\title{
Synthesis and Properties of a Novel Electrochromic Polymer Obtained from the Electropolymerization of a 9,9'-Spirobifluorene-Bridged Donor-Acceptor (D-A) Bichromophore System
}

\author{
Luis Otero, ${ }^{\dagger}$ Leonides Sereno, ${ }^{\dagger}$ Fernando Fungo, ${ }^{*}{ }^{\dagger}$ Yuan-Li Liao,${ }^{\ddagger}$ Chi-Yen Lin,,${ }^{\ddagger}$ and \\ Ken-Tsung Wong* $*$ \\ Departamento de Química, Universidad Nacional de Río Cuarto, Agencia Postal 3 (5800), \\ Río Cuarto, Argentina, and Department of Chemistry, National Taiwan University, Taipei 106, Taiwan
}

Received March 3, 2006

\begin{abstract}
The synthesis and photophysical, electrochemical, and spectroelectrochemical characterization of a novel donor-acceptor (D-A) bichromophore system composed of two D-A segments linking through a spiro center are reported. The electron-donating (D) moieties are triphenylamine (TPA) groups, whereas the electron-withdrawing (A) moieties are cyano groups. The particular "spiro" configuration that perpendicularly bonds the $\mathrm{D}-\mathrm{A}$ chromophores by a tetrahedral carbon, impedes orbital interactions between the branches. Thus, the two TPA substituents act independently, rendering an efficient electropolymerization process feasible. The polymer film obtained showed reversible electrochemical oxidation accompanied by strong color changes with high coloration efficiency and contrast ratio, which can be switched by potential modulation. The remarkable electrochromic behavior of the film is clearly interpreted on the basis of spectroelectrochemical studies. A plausible polymerization mechanism involved with the TPA dimerization reaction is proposed for the electropolymerization process.
\end{abstract}

\section{Introduction}

Polymeric and oligomeric materials applied in thin layer electro-optical devices such as organic light emitting diodes (OLEDs), solar cells, and organic field effect transistors (OTFTs $)^{1}$ should exhibit reasonable electronic conductivity and adequate band-gap energies or light absorption/emission in the desired region of the electromagnetic spectrum. For example, low-band-gap polymers with absorption bands in the near-infrared region can be obtained by maximizing the $\pi$-electron delocalization within the conjugated polymer backbone through aromatic and quinoid type structures adopting coplanar conformations between the polymer's consecutive repeating units. ${ }^{2 \mathrm{a}-\mathrm{c}, 3 \mathrm{a}} \mathrm{Common}$ examples are the classical conducting polymers ${ }^{4}$ such as polyaniline, ${ }^{5-7}$ polythiophenes ${ }^{8,9}$ and polypyrroles. ${ }^{10}$

Another strategy employed in designing polymeric structures with desired electronic properties involves the synthesis

* To whom correspondence should be addressed. E-mail: ffungo@ exa.unrc.edu.ar (F.F.), kenwong@ntu.edu.tw. (K.-T.W.).

${ }^{\dagger}$ Universidad Nacional de Río Cuarto.

* National Taiwan University.

(1) (a) Thelakkat, M. Macromol. Mater. Eng. 2002, 287, 442. (b) Cumpston, B. H.; Ananthavel, S. P.; Barlow, S.; Dyer, D. L.; Ehrlich, J. E.; Erskine, L. L.; Heikal, A. A.; Kuebler, S. M.; Lee, I. Y. S.; McCord-Maughon, D.; Qin, J.; Rochkel, H.; Rumi, M.; Wu, X. L.; Marder, S. R.; Perry, J. W. Nature 1999, 398, 51. (c) Drobizhev, M.; Karotki, A.; Dzenis, Rebane, A.; Suo, Z. Y.; Spangler, C. W. J. Phys. Chem. B 2003, 107, 7540.

(2) (a) Brédas, J. L. J. Chem. Phys. 1985, 82, 3808. (b) Jenekhe, S. A. Nature 1986, 322, 345. (c) Chen, W. C.; Jenekhe, S. A. Macromolecules 1995, 28, 465.

(3) (a) Roncali, J. Chem. Rev. 1997, 97, 173. (b) Agrawal, A. K.; Jenekhe, S. A. Macromolecules 1993, 26, 895.

(4) Skotheim, T. A.; Elsenbaumer, R. L.; Reynolds, J. R. Handbook of Conducting Polymers, 2nd ed.; Marcel Dekker: New York, 1997. of the donor-acceptor $(\mathrm{D}-\mathrm{A})$ type polymers in which the $\mathrm{A}$ and D units are strong electron-withdrawing (A) and electron-donating (D) moieties, respectively. ${ }^{3 \mathrm{a}-\mathrm{b}, 11,12}$ Making appropriate choices for the $\mathrm{A}$ and $\mathrm{D}$ units allows one to control of the $\pi$-system's HOMO and LUMO energy levels. Therefore, the properties such as redox behavior and photophysical characteristics of the polymers can be tailored. In addition, because of the electronic nature of $\mathrm{D}-\mathrm{A}$ polymers, they are able to show two different redox processes (oxidation and reduction), depending on which moiety (D or A) is involved.

In this paper, we report the synthesis and photophysical, electrochemical, and spectroelectrochemical studies of a novel D-A chromophore system composed of two D-A segments linking through a spiro center (Scheme 1). This molecule is basically a D-A type chromophore in which the electron-donating (D) moiety is a triphenylamine (TPA) group and the electron-withdrawing (A) moiety is a cyano group. Upon oxidation, the TPA can undergo well-known radical cation dimerization to produce the tetraphenylben-

(5) Rodrigues, M. A.; De Paoli, M. A.; Mastragostino, M. Electrochim. Acta 1991, 36, 2143.

(6) Panero, S.; Scrosati, B.; Baret, M.; Cecchini, B.; Masetti, E. Sol. Energy Mater. Sol. Cells 1995, 39, 239.

(7) Tassi, E. L.; De Paoli, M. A. Electrochim. Acta 1994, 39, 2481.

(8) Dietrich, M.; Heinze, J.; Heywang, G.; Jonas, F. J. Electroanal. Chem. 1994, $369,87$.

(9) Sapp, S. A.; Sotzing, G. A.; Reynolds, J. R. Chem. Mater. 1998, 10, 2101.

(10) De Paoli, M. A.; Zanelli, A.; Mastragostino, M.; Rocco, A. M. $J$. Electroanal. Chem 1997, 435, 217.

(11) Zhang, Q. T.; Tour, J. M. J. Am. Chem. Soc. 1998, 120, 5355.

(12) Devasagayaraj, A.; Tour, J. M. Macromolecules 1999, 32, 6425. 
zidine (TPB), which does not effectively couple to give polymers because of the high delocalization of the radical cation between the two nitrogen atoms. ${ }^{13-16}$ However, it has been reported that blocking the radical cation delocalization can be achieved by introducing electron-deficient components between two TPA units, leading to an improvement in their reactivity toward electropolymerization. ${ }^{17}$ The particular spiro configuration that perpendicularly bonds two D-A chromophores with a tetrahedral carbon impedes the $\pi$-orbital interaction between the different $\mathrm{D}-\mathrm{A}$ chromophore branches. Thus, the two TPA substituents could act independently, rendering the electropolymerization processes feasible. In addition, these kinds of $\mathrm{D}-\mathrm{A}$ structures, implanted with a rigid and coplanar fluorene ring, may lead to a good emitter with promising potential applications in OLEDs. ${ }^{18-20}$

\section{Experimental Section}

Synthetic Procedures. Synthesis of 7,7'-Dibromo-9,9'-spirobifluorene-2,2'-bis(carboxylic acid methyl ester) (2). To a solution of 7,7'-dibromo-9,9'-spirobifluorene-2,2'-dicarboxylic acid $(5.62 \mathrm{~g}$, $10 \mathrm{mmol})$ in methanol $(90 \mathrm{~mL})$ was slowly added sulfuric acid (10 $\mathrm{mL}$ ). The solution was allowed to reflux for 3 days. The white solid was collected and washed with methanol to afford white diester $2(5.3 \mathrm{~g}, 90 \%)$. Mp: $307-309^{\circ} \mathrm{C}$. IR (KBr): $v 3058(\mathrm{w})$, 2985 (w), 2952 (w), 1719 (s), 1613 (m), 1427 (m), 1301 (s), 1255 (s) $\mathrm{cm}^{-1} .{ }^{1} \mathrm{H}$ NMR $\left(\mathrm{CDCl}_{3}, 400 \mathrm{MHz}\right): \delta 8.12(\mathrm{dd}, J=8.0,1.4$ $\mathrm{Hz}, 2 \mathrm{H}), 7.89(\mathrm{~d}, J=8.0 \mathrm{~Hz}, 2 \mathrm{H}), 7.77(\mathrm{~d}, J=8.0 \mathrm{~Hz}, 2 \mathrm{H}), 7.56$ $(\mathrm{dd}, J=8.0,1.6 \mathrm{~Hz}, 2 \mathrm{H}), 7.35(\mathrm{~s}, 2 \mathrm{H}), 6.84(\mathrm{~d}, J=1.4 \mathrm{~Hz}, 2 \mathrm{H})$, $3.79(\mathrm{~s}, 6 \mathrm{H}) .{ }^{13} \mathrm{C} \mathrm{NMR}\left(\mathrm{CDCl}_{3}, 100 \mathrm{MHz}\right): \delta 166.5,150.0,147.0$, 145.2, 139.5, 131.8, 130.4, 130.1, 127.4, 125.3, 123.1, 122.5, 120.2, 50.1. MS $\left(m / z, \mathrm{FAB}^{+}\right)$: 590 (12), 559 (15), 460 (10), 329 (30), 307 (100), 289 (53). Anal. Calcd: C, 59.01; H, 3.07. Found: C, 58.79; H, 2.96.

Synthesis of 2,2'-Dibromo-7,7'-bis(hydroxymethyl)-9,9'-spirobifluorene (3). A solution of diester $2(5.9 \mathrm{~g}, 10 \mathrm{mmol})$ in THF $(150 \mathrm{~mL})$ was stirred under $\mathrm{N}_{2}$ and cooled to $0{ }^{\circ} \mathrm{C}$. Diisobutylaluminum hydride ( $45 \mathrm{~mL}, 1.0 \mathrm{M}$ in hexane solution) was slowly added. The reaction was allowed to warm to room temperature and was stirred for another $4 \mathrm{~h}$. The mixture was quenched with $10 \%$ sodium hydroxide solution $(6 \mathrm{~mL})$, and the precipitate was filtered out. The solvent was evaporated and then extracted with $\mathrm{CH}_{2} \mathrm{Cl}_{2}$. The organic phase was collected and dried over anhydrous $\mathrm{MgSO}_{4}$. After the solvent was evaporated in vacuo, the white solid was washed with hexane to afford white dihydroxy compound 3 (5.32 g, 86\%). Mp: $276-278^{\circ} \mathrm{C}$; IR (KBr): v 3946 (m), 3761 (w), 3695 (w), 3045 (s), 2979 (s), 2693 (m), 2395 (m), 2302 (s), 1427 (s), $1248(\mathrm{~s}), 897(\mathrm{~m}), 724(\mathrm{~s}) \mathrm{cm}^{-1} .{ }^{1} \mathrm{H}$ NMR $\left(\mathrm{CDCl}_{3}, 400 \mathrm{MHz}\right): \delta$ $7.79(\mathrm{~d}, J=8.0 \mathrm{~Hz}, 2 \mathrm{H}), 7.69(\mathrm{~d}, J=8.0 \mathrm{~Hz}, 2 \mathrm{H}), 7.50(\mathrm{dd}, J=$ 8.0, $2.0 \mathrm{~Hz}, 2 \mathrm{H}), 7.38(\mathrm{~d}, J=7.2 \mathrm{~Hz}, 2 \mathrm{H}), 6.82(\mathrm{~d}, J=1.6 \mathrm{~Hz}$,

(13) Oyama, M.; Nozaki, K.; Okazaki, S. Anal. Chem. 1991, 63, 1387.

(14) Seo, E. T.; Nelson, R. F.; Fritsch, J. M.; Marcoux, L. S.; Leedy, D. W.; Adams, R. N. J. Am. Chem. Soc. 1966, 88, 3498.

(15) Creason, S. C.; Wheeler, J.; Nelson, R. F. J. Org. Chem. 1972, 37, 4440.

(16) Zhang, T.; Toth, B. Anal. Chem. 2000, 72, 2533.

(17) Leung, M.-k.; Chou, M.-Y.; Su, Y.-O.; Chiang, C.-L.; Chen, H.-L.; Yang, C.-F. Yang, C.-C.; Lin, C.-C.; Chen, H.-T. Org. Lett. 2003, 5, 839.

(18) Fungo, F.; Wong, K.-T.; Ku, S.-Y.; Hung, Y.-Y.; Bard, A. J. J. Phys. Chem. B 2005, 109, 3984.

(19) Patra, A.; Pan, M.; Friend, C. S.; Lin, T. C.; Cartwright, A. N.; Prasad, P. N. Chem. Mater. 2002, 14, 4044.

(20) Chiang, C.-L.; Wu, M.-F.; Dai, D.-C.; Wen, Y.-S.; Wang, J.-K.; Chen, C.-T. Adv. Funct. Mater. 2005, 15, 231.
2H), 6.69 (s, 2H), $4.54(\mathrm{~s}, 4 \mathrm{H}) .{ }^{13} \mathrm{C} \mathrm{NMR}\left(\mathrm{CDCl}_{3}, 100 \mathrm{MHz}\right) \delta$ 149.4, 147.4, 140.8, 139.9, 139.6, 130.8, 126.9, 126.7, 122.2, 121.2, 121.1, 119.9, 65.5, 65.1. MS ( $\left.\mathrm{m} / \mathrm{z}, \mathrm{FAB}^{+}\right)$: 534 (40), 516 (50), 460 (10), 369 (5), 341 (10), 307 (100), 289 (60). Anal. Calcd: C, 60.70 ; H, 3.40. Found: C, 60.36; H, 3.30.

Synthesis of 2,2'-Dibromo-7,7'-bis(bromomethyl)-9,9'-spirobifluorene (4). A solution of dihydroxy compound 3 (5.32 g, 10 mmol) in $\mathrm{CH}_{2} \mathrm{Cl}_{2}(100 \mathrm{~mL})$ was slowly added with $\mathrm{PBr}_{3}(9.6 \mathrm{~mL}$, $100 \mathrm{mmol}$ ). After being stirred $2 \mathrm{~h}$ at room temperature, the mixture was poured into water and extracted with $\mathrm{CH}_{2} \mathrm{Cl}_{2}$. The organic phase was collected, dried over anhydrous $\mathrm{MgSO}_{4}$, then concentrated by rotary evaporation. The solid was washed with hexane to afford white product tetrabromo compound 4 (6.27 g, 95\%). MpL 267$268{ }^{\circ} \mathrm{C}$. IR (KBr): v $3946(\mathrm{~m}), 3767$ (w), 3688 (w), 3058 (s), 2979 (s), $2700(\mathrm{~m}), 2322(\mathrm{~s}), 1732(\mathrm{w}), 1427$ (s), 1275 (s), 903 (s), 718 (m) $\mathrm{cm}^{-1} .{ }^{1} \mathrm{H}$ NMR $\left(\mathrm{CDCl}_{3}, 400 \mathrm{MHz}\right): \delta 7.79(\mathrm{~d}, J=8.4 \mathrm{~Hz}$, $2 \mathrm{H}), 7.70(\mathrm{~d}, J=8.0 \mathrm{~Hz}, 2 \mathrm{H}), 7.52(\mathrm{dd}, J=8.0,1.6 \mathrm{~Hz}, 2 \mathrm{H}), 7.47$ $(\mathrm{dd}, J=8.0,1.6 \mathrm{~Hz}, 2 \mathrm{H}), 6.82(\mathrm{~d}, J=2.0 \mathrm{~Hz}, 2 \mathrm{H}), 6.70(\mathrm{~d}, J=$ $1.2 \mathrm{~Hz}, 2 \mathrm{H}), 4.36(\mathrm{~s}, 4 \mathrm{H}) .{ }^{13} \mathrm{C} \mathrm{NMR}\left(\mathrm{CDCl}_{3}, 100 \mathrm{MHz}\right): \delta 149.6$, 147.6, 140.7, 139.8, 138.0, 131.4, 129.6, 127.2, 124.4, 121.9, 121.5, 120.5, 65.3, 33.3. MS ( $\left.\mathrm{m} / \mathrm{z}, \mathrm{FAB}^{+}\right): 663$ (10), 460 (15), 369 (20), 307 (100), 289 (50). Anal. Calcd: C, 49.13; H, 2.44. Found: C, 49.15; H, 2.52 .

Synthesis of 2,2'-Dibromo-7,7'-bis(diethyl methylphosphonate)9,9'-spirobifluorene (5). A mixture of tetrabromo 4 (0.66 g, $1 \mathrm{mmol})$ and triethyl phosphite $(1.0 \mathrm{~mL})$ was heated under reflux for $8 \mathrm{~h}$. The mixture was quenched with water and then extracted with $\mathrm{CH}_{2-}$ $\mathrm{Cl}_{2}$. The organic layer was collected and dried over anhydrous $\mathrm{MgSO}_{4}$. After $\mathrm{CH}_{2} \mathrm{Cl}_{2}$ was evaporated, excess triethyl phosphite was evaporated at $140{ }^{\circ} \mathrm{C}$ under a vacuum $(0.05$ Torr $)$. The residue was allowed to cool to room temperature and purified by precipitation from $\mathrm{CH}_{2} \mathrm{Cl}_{2}$ and hexane to afford white diphosphite compound 5 (0.66 g, 85\%). Mp: $113-114{ }^{\circ} \mathrm{C}$. IR (KBr): v 3940 (m), 3754 (w), 3695 (w), 3058 (s), 2985 (s), 2693 (m), 2402 (m), 2302 (s), 1427 (s), 1275 (s), 1029 (m), 903 (s) cm ${ }^{-1} .{ }^{1} \mathrm{H} \mathrm{NMR}\left(\mathrm{CDCl}_{3}, 400\right.$ $\mathrm{MHz}): \delta 7.76(\mathrm{~d}, J=7.6 \mathrm{~Hz}, 2 \mathrm{H}), 7.68(\mathrm{~d}, J=8.4 \mathrm{~Hz}, 2 \mathrm{H}), 7.49$ $(\mathrm{d}, J=7.6 \mathrm{~Hz}, 2 \mathrm{H}), 7.35$ (d, $J=7.6 \mathrm{~Hz}, 2 \mathrm{H}), 6.80(\mathrm{~s}, 2 \mathrm{H}), 6.58$ $(\mathrm{s}, 2 \mathrm{H}), 3.90-3.76(\mathrm{~m}, 6 \mathrm{H}), 3.07-2.90(\mathrm{~m}, 4 \mathrm{H}), 1.06(\mathrm{q}, J=6.8$ $\mathrm{Hz}, 6 \mathrm{H}) .{ }^{13} \mathrm{C} \mathrm{NMR}\left(\mathrm{CDCl}_{3}, 100 \mathrm{MHz}\right): \delta$ 149.5, 147.6, 140.2, $139.1,131.9,131.1,129.8,127.0,125.1,121.3,120.3,65.2,62.3$, 62.0, 34.5, 33.1, 16.3. MS (m/z, FAB $\left.{ }^{+}\right): 776(10), 775(10), 663$ (10), 549 (20), 327 (20), 281 (50), 207 (100). HRMS ((M + $\left.\mathrm{H}^{+}\right)$, $\mathrm{FAB}^{+}$): calcd for $\mathrm{C}_{35} \mathrm{H}_{37}{ }^{79} \mathrm{Br}^{79} \mathrm{BrO}_{6} \mathrm{P}_{2}, 773.0432$; found, 773.0421; calcd for $\mathrm{C}_{35} \mathrm{H}_{37}{ }^{79} \mathrm{Br}^{81} \mathrm{BrO}_{6} \mathrm{P}_{2}, 775.0412$; found, 775.0400; calcd for $\mathrm{C}_{35} \mathrm{H}_{37}{ }^{81} \mathrm{Br}^{81} \mathrm{BrO}_{6} \mathrm{P}_{2}, 777.0391$; found, 777.0406.

Synthesis of 2,2'-Dibromo-7,7'-bis(4''-N,N-diphenylaminostyryl)9,9'-spirobifluorene (6). A solution of diphosphite 5 (774 mg, 1 $\mathrm{mmol}$ ) and 4-N,N-diphenylaminobenzaldehyde (546 mg, $2 \mathrm{mmol}$ ) in anhydrous THF $(20 \mathrm{~mL})$ was added to a solution of potassium tert-butoxide $(0.83 \mathrm{~g}, 10 \mathrm{mmol})$ in anhydrous THF $(20 \mathrm{~mL})$ at 0 ${ }^{\circ} \mathrm{C}$ for $16 \mathrm{~h}$. The solution was extracted with $\mathrm{CH}_{2} \mathrm{Cl}_{2}$. The organic layer was collected and dried over anhydrous $\mathrm{MgSO}_{4}$. After $\mathrm{CH}_{2-}$ $\mathrm{Cl}_{2}$ was evaporated, the solid was washed with hexane to afford light yellow product dibromo compound 6 (0.912 g, 90\%). Mp: 325-327 ${ }^{\circ} \mathrm{C}$. IR (KBr): v 3953 (m), 3761 (w), $3688(\mathrm{w}), 3058$ (s), 2979 (s), 2680 (m), 2395 (w), 2309 (s), 1427 (s), 1255 (s), 897 (s), $738(\mathrm{~s}) \mathrm{cm}^{-1} .{ }^{1} \mathrm{H}$ NMR (DMSO- $\left.d_{6}, 400 \mathrm{MHz}\right): \delta 8.05$ (d, $J=$ $8.0 \mathrm{~Hz}, 2 \mathrm{H}), 8.00(\mathrm{~d}, J=8.0 \mathrm{~Hz}, 2 \mathrm{H}), 7.69(\mathrm{~d}, J=8.0 \mathrm{~Hz}, 2 \mathrm{H})$, $7.62(\mathrm{dd}, J=8.0,1.6 \mathrm{~Hz}, 2 \mathrm{H}), 7.40(\mathrm{~d}, J=7.6 \mathrm{~Hz}, 4 \mathrm{H}), 7.27$ (t, $J=8.0 \mathrm{~Hz}, 8 \mathrm{H}), 7.06-6.97(\mathrm{~m}, 16 \mathrm{H}), 6.84(\mathrm{~d}, J=8.4 \mathrm{~Hz}, 6 \mathrm{H})$, $6.76(\mathrm{~d}, J=1.8 \mathrm{~Hz}, 2 \mathrm{H}) .{ }^{13} \mathrm{C} \mathrm{NMR}\left(\mathrm{CDCl}_{3}, 100 \mathrm{MHz}\right): \delta 150.2$, 148.2, 147.5, 147.4, 140.4, 139.7, 138.2, 131.3, 131.1, 129.2, 128.5, 127.3, 126.7, 126.4, 124.5, 123.2, 123.0, 121.7, 121.4, 121.3, 120.4, 65.4. MS (m/z, $\left.\mathrm{FAB}^{+}\right)$: 1014 (5), 732 (5), 663 (10), 549 (15), 460 

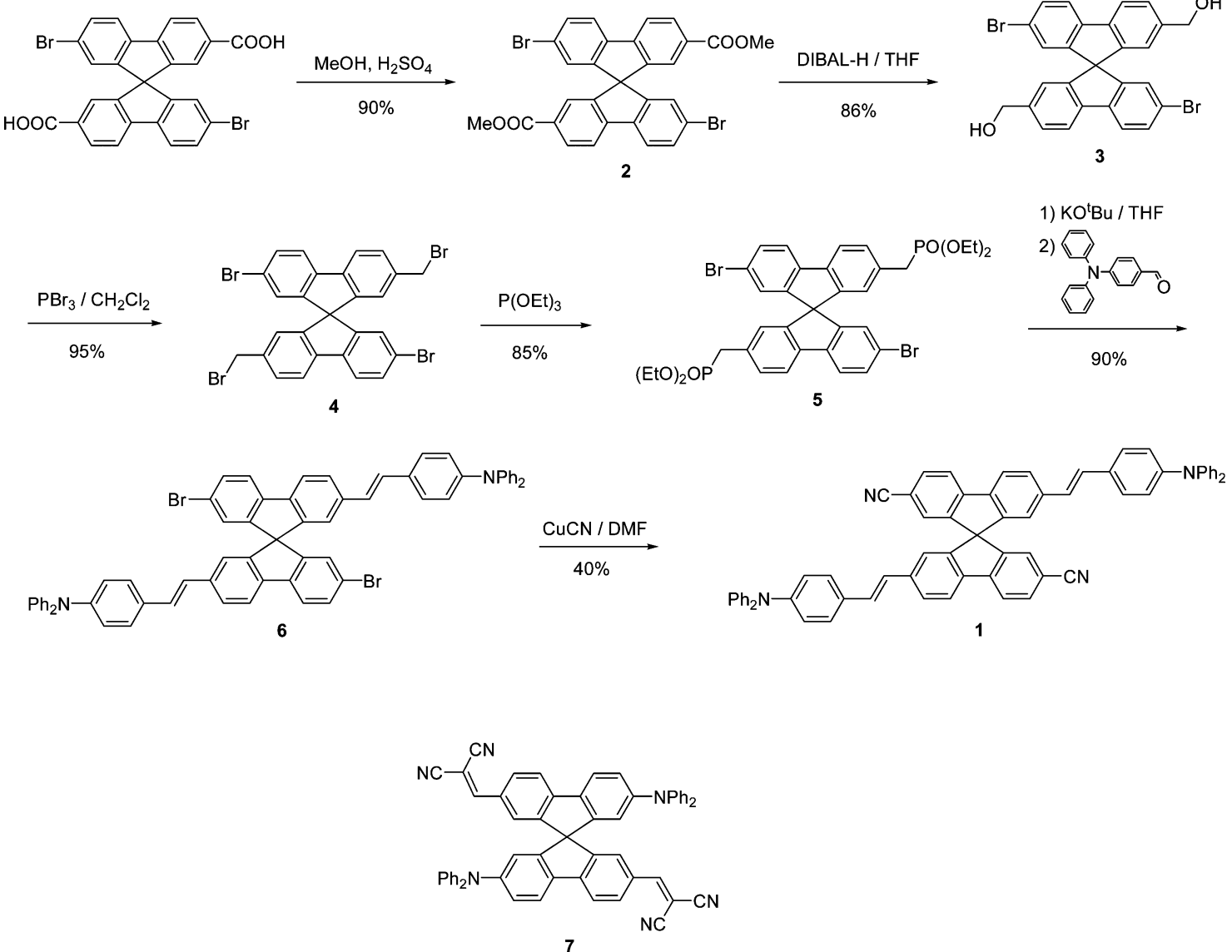

(10), 369 (20), 307 (100). HRMS $\left(\mathrm{M}^{+}, \mathrm{FAB}^{+}\right)$: calcd for $\mathrm{C}_{65} \mathrm{H}_{44}{ }^{79}$ $\mathrm{Br}^{79} \mathrm{BrN}_{2}$, 1010.1871; found, 1010.1821; calcd for $\mathrm{C}_{65} \mathrm{H}_{44}{ }^{79} \mathrm{Br}^{81}$ $\mathrm{BrN}_{2}$, 1012.1851; found, 1012.1856; calcd for $\mathrm{C}_{65} \mathrm{H}_{44}{ }^{81} \mathrm{Br}^{81} \mathrm{BrN}_{2}$, 1014.1830; found, 1014.1860.

Synthesis of 2,2'-Dicyano-7,7'-bis(4''-N,N-diphenylaminostyryl)9,9'-spirobifluorene (1). A mixture of dibromo compound 6 (450 $\mathrm{mg}, 0.44 \mathrm{mmol}$ ) and copper cyanide (315 $\mathrm{mg}, 3.52 \mathrm{mmol}$ ) in DMF $(20 \mathrm{~mL})$ was heated under reflux for $48 \mathrm{~h}$. The reaction was quenched with ammonium water $(30 \mathrm{~mL})$ and then extracted with $\mathrm{CH}_{2} \mathrm{Cl}_{2}$. The organic layer was collected and dried over anhydrous $\mathrm{MgSO}_{4}$. After $\mathrm{CH}_{2} \mathrm{Cl}_{2}$ was evaporated, the solid was purified by column chromatography on silica gel (hexane/ethyl acetate $=4 / 1$ ) to afford the final product 1 as a yellow solid (160 mg, 40\%). Mp: 218-220 ${ }^{\circ} \mathrm{C}$. IR (KBr): v 3946 (m), 3761 (m), 3058 (s), 2979 (s), 2687 (w), 2309 (s), 1593 (w), 1420 (s), 1281 (s), 903 (s) cm ${ }^{-1} \cdot{ }^{1} \mathrm{H}$ NMR (DMSO- $\left.d_{6}, 400 \mathrm{MHz}\right): \delta 8.25$ (d, $\left.J=8.0 \mathrm{~Hz}, 2 \mathrm{H}\right), 8.18$ (d, $J=8.0 \mathrm{~Hz}, 2 \mathrm{H}), 7.91(\mathrm{dd}, J=8.0,1.2 \mathrm{~Hz}, 2 \mathrm{H}), 7.76(\mathrm{~d}, J=8.0$ $\mathrm{Hz}, 2 \mathrm{H}), 7.41$ (d, $J=8.0 \mathrm{~Hz}, 4 \mathrm{H}), 7.28(\mathrm{t}, J=8.0 \mathrm{~Hz}, 8 \mathrm{H}), 7.15$ (s, 2H), 7.11 (s, 2H), 7.06-6.98 (m, 14H), 6.89 (s, 2H), 6.85 (d, $J$ $=8.4 \mathrm{~Hz}, 4 \mathrm{H}) \cdot{ }^{13} \mathrm{C} \mathrm{NMR}\left(\mathrm{CDCl}_{3}, 100 \mathrm{MHz}\right): \delta 148.4,148.2$, 147.6, 147.3, 145.8, 139.8, 138.7, 132.6, 130.5, 129.6, 129.2, 127.5, 127.4, 127.1, 125.7, 124.6, 123.1, 122.9, 121.7, 121.6, 120.7, 118.7, 110.8, 65.2. MS (m/z, $\left.\mathrm{FAB}^{+}\right): 904.4(40), 663.4$ (100), 662.4 (60), 607.4 (10), 459.2 (10), 369.3 (5), 258.1 (20), 219.3 (10). HRMS $\left(\mathrm{M}^{+}, \mathrm{FAB}^{+}\right)$: calcd for $\mathrm{C}_{67} \mathrm{H}_{44} \mathrm{~N}_{4}, 904.3566$; found, 904.3586 .

Electrochemical Characterization. Electrochemical experiments were conducted with a potentiostat-galvanostat Autolab (Electrochemical Instruments) employing a three-electrode cell at room temperature. The electrolyte solution as supporting electrolyte consisted of an acetonitrile (MeCN, anhydrous) solution with 0.1 $\mathrm{M}$ tetra- $n$-butylammonium perchlorate (TBAP). The working electrode consisted of a $2.16 \times 10^{-3} \mathrm{~cm}^{2}$ inlaid platinum disk that was polished on a felt pad with $0.3 \mu \mathrm{m}$ alumina and sonicated in water and absolute ethanol for $3 \mathrm{~min}$ each; it was then dried in an oven at $50{ }^{\circ} \mathrm{C}$. A platinum coil was used as the counterelectrode and a silver wire was used as a pseudo-reference electrode. All potential values in this study are expressed relative to a silver pseudo-reference electrode (Ag). The ferrocene/ferrocenium redox couple $\left(\mathrm{Fc} / \mathrm{Fc}^{+}\right)$was added to the electrolyte as an internal standard and shows an oxidation potential value of $0.37 \mathrm{~V}$ vs Ag.

Spectroelectrochemical experiments were carried out in a homemade cell built from a commercial UV-visible cuvette. The ITO-coated glass (a piece that fit in the cuvette) was used as the working electrode, a platinum wire as the counter electrode, and an Ag wire as the reference electrode. The cell was placed in the optical path of the sample light beam in a Hewlett-Packard diode array (model 8453) spectrophotometer. The background correction was obtained by taking a UV-vis spectrum of a blank cell (an electrochemical cell with an ITO working electrode without the polymer film) with conditions and parameters identical to those of the polymer experiment.

\section{Results and Discussion}

Synthesis. The synthesis of spiro-configured D-A molecule 1 is shown in Scheme 1. Esterification of 2,2'-dibromo$9,9^{\prime}$-spirobifluorene-7,7'-dicarboxylic acid ${ }^{21}$ with methanol in the presence of sulfuric acid afforded diester $\mathbf{2}$ in $90 \%$ yield. The ester groups of $\mathbf{2}$ were subsequently reduced to alcohol with diisobutylaluminum hydride (DIBAL-H) at low temperature to give dialcohol 3 in $86 \%$ yield. The hydroxy

(21) Pudzich, R.; Salbeck, J. Synth. Met. 2003, 138, 21. 


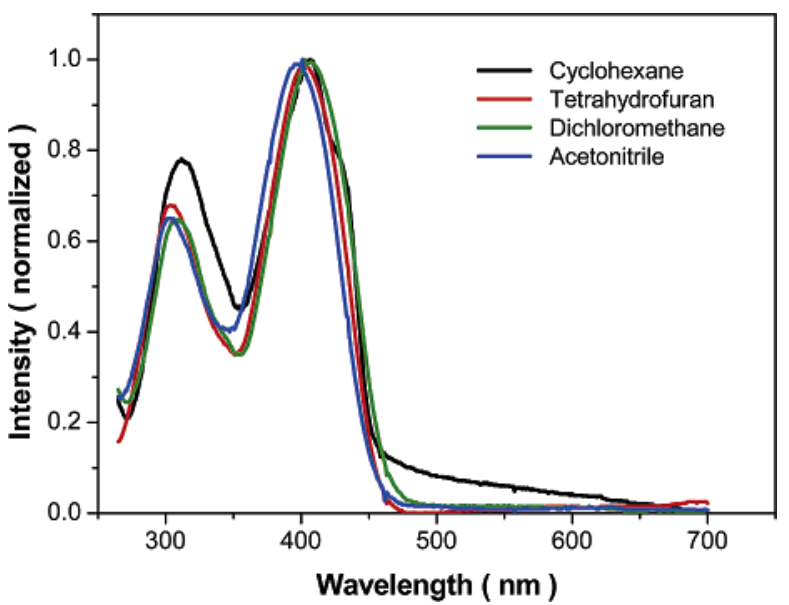

Figure 1. Absorption spectra of $\mathbf{1}$ in different solvents.

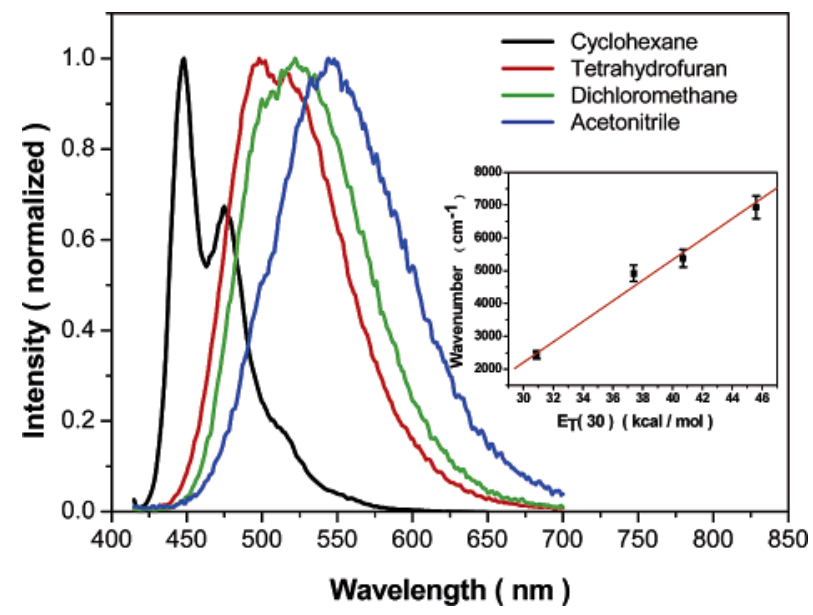

Figure 2. Photoluminescence spectra of $\mathbf{1}$ in different solvents; inset shows the Lippert plots of emission peaks as a function of solvent polarities.

groups in $\mathbf{3}$ were then converted to bromo groups by treating it with an excess amount of $\mathrm{PBr}_{3}$. Treatment of the resulting tetrabromo compound $\mathbf{4}$ with triethyl phosphite afforded the diethyl phosphite compound $\mathbf{5}$ in $85 \%$ yield. The donor moiety (an $N, N$-diphenyl aminophenylene group) was then introduced by Wittig-Horner olefination of 4- $\mathrm{N}, \mathrm{N}$-diphenylaminobenzaldehyde with the diethyl phosphite compound 5 in the presence of $\mathrm{K}^{t} \mathrm{OBu}$ as a strong base. The acceptor moieties (cyano groups) were introduced by treating the dibromo compound $\mathbf{6}$ with $\mathrm{CuCN}$ in refluxing DMF to give the final product in $40 \%$ yield after column chromatography purification. A similar spiro-configured bichromophore molecule 7 (Scheme 1) is used for comparison studies. The synthesis and characterization of molecule 7 (Scheme 1) have been described elsewhere. ${ }^{22}$

Photophysical Properties. The absorption and emission spectra of spiro-configured D-A system $\mathbf{1}$ were studied in different organic solvents. Figures 1 and 2 depict the steadystate absorption and emission spectra of $\mathbf{1}$, respectively, in various solvents. The absorption peak wavelength is nearly solvent-polarity independent, indicating a small interaction between $\mathrm{D}$ and $\mathrm{A}$ in the ground state. In contrast, the emission spectra of $\mathbf{1}$ show a strong solvent-polarity dependence, exhibiting broad emission bands that undergo sig-

(22) Chiang, C.-L.; Shu, C.-F.; Chen, C.-T. Org. Lett. 2005, 7, 3717.

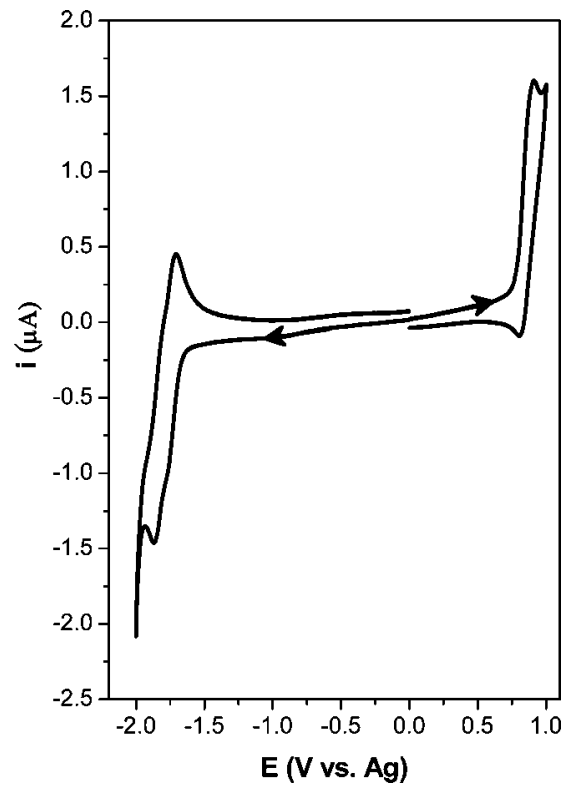

Figure 3. Cyclic voltammogram of $\mathbf{1}\left(7.6 \times 10^{-4} \mathrm{M}\right)$ on a Pt electrode in $\mathrm{MeCN}$ with $0.1 \mathrm{M}$ TBAP, $v=0.3 \mathrm{~V} \mathrm{~s}^{-1}$, area of electrode $=2.16 \times 10^{-3}$ $\mathrm{cm}^{2}$.

nificant bathochromic shifts as the solvent polarity increases. For example, 1 displays an emission band centered at 447 $\mathrm{nm}$ in cyclohexane, which is then red-shifted to as far as $546 \mathrm{~nm}$ in acetonitrile. In all solvents studied, the excitation spectra are effectively identical to the absorption profiles, excluding the possibility of trace impurities. On the basis of the absorption and emission spectroscopy, it is most likely incorrect to attribute the emission simply to a solvatochromism process, in which a remarkable change of dipole moment takes place upon excitation. Alternatively, the results can be more plausibly attributed to a mechanism involving a fast photoinduced electron-transfer (PET) process, resulting in a large change of dipole moment in the excited state. Subsequently, because of the unstable solvation environment, a solvent relaxation process takes place, leading to the solvent-polarity-dependent emission. ${ }^{23,24}$

Electrochemical Characterization. Cyclic voltammetry (CV) was used to obtain information about the redox behavior and the electrogenerated radical ions stability of spiro-configured D-A systems $\mathbf{1}$ and $\mathbf{7}$. The electrochemistry was studied in acetonitrile $(\mathrm{MeCN})$ containing $0.1 \mathrm{M}$ tetra$n$-butylammonium perchlorate (TBAP) as a supporting electrolyte. The first CV of $\mathbf{1}$ obtained on a Pt electrode is shown in Figure 3. In agreement with our expectations for these kinds of molecules, the $\mathrm{CV}$ shows two redox responses, one of them centered around $1.0 \mathrm{~V}$ that is assigned to the oxidation of $\mathrm{D}$ units, and another centered around $-1.75 \mathrm{~V}$ that corresponds to the reduction of A moieties. On the other hand, both cathodic and anodic processes give a very similar peak profile, and the current peaks show the same values within the experimental error. This fact suggests that equal numbers of electrons are exchanged. On the other hand,

(23) Chien, Y.-Y.; Wong, K.-T.; Chou, P.-T.; Cheng, Y.-M. Chem. Commun. 2002, 2874.

(24) Wong, K.-T.; Ku, S.-Y.; Cheng, Y.-M.; Lin, X.-Y.; Hung, Y.-Y.; Pu, S.-C.; Chou, P.-T.; Lee, G.-H.; Peng, S.-M. J. Org. Chem. 2006 , $71,456$. 
in the reverse scan of the anodic sweep, the complementary reduction peak shows an $i_{\mathrm{p}}$ backward/i $i_{\mathrm{p}}$ forward relationship less than one $\left(i_{\mathrm{pc}} / i_{\mathrm{pa}} \ll 1\right)$ in the entire range of scan rate studied $\left(0.05-2.00 \mathrm{~V} \mathrm{~s}^{-1}\right)$. This behavior is typical for an irreversible chemical reaction coupled to heterogeneous charge transfer. ${ }^{25-27}$ We estimated the apparent number of electron exchanged in the overall electrode processes by comparison of the experimental current function $(\psi)$ with model compounds. ${ }^{28,29}$ The experimental $\psi$ can be defined as $\psi=i_{\mathrm{p}} /\left(A v^{1 / 2} C^{*}\right)$, where $A$ is the working electrode area, in $\mathrm{cm}^{2}, v$ the potential scan rate in $\mathrm{V} \mathrm{s}^{-1}$, and $C^{*}$ the bulk concentration of species in M. In similar experimental conditions, ferrocene was selected as a model for oneelectron exchange $\left(\psi=0.73 \mathrm{~A}\left(\mathrm{~V} \mathrm{~s}^{-1}\right)^{-1 / 2} \mathrm{~cm}^{-2} \mathrm{M}^{-1}\right)$, and $N, N, N^{\prime}, N^{\prime}$-tetramethyl-1,1-naphthidine as a two-electron exchange model ${ }^{30}\left(\psi=1.80 \mathrm{~A}\left(\mathrm{~V} \mathrm{~s}^{-1}\right)^{-1 / 2} \mathrm{~cm}^{-2} \mathrm{M}^{-1}\right)$. We calculated for both anodic and cathodic processes at different scan rates a value of $\psi \approx 1.8$, indicating that the number of electrons exchanged in the overall electrode processes is two.

The electro-oxidation of TPA was extensively studied by others. ${ }^{31-35}$ All those studies concluded that the radical cation formed by oxidation is involved in a dimerization reaction that produced tetraphenylbenzidine (TPB). The electrochemical processes can be described by an $\mathrm{EC}_{2} \mathrm{E}$ mechanism, ${ }^{36}$ where the dimerization reaction is second order. The TPB has a lower oxidation potential than TPA because of its moreextended $\pi$-electron delocalization. However, when $\mathbf{1}$ is successively cycled between 0 and $1.2 \mathrm{~V}$, the current increases, indicating the characteristic behavior of the formation of a deposited electroactive film. Typical multiple CV scans of dipolar molecule $\mathbf{1}$ on a Pt electrode are shown in Figure 4.Moreover, when a Pt electrode, which has been treated as previously described, is removed from the cell and subsequently rinsed with $\mathrm{MeCN}$ and transferred to a molecule 1 free-electrolyte solution, it shows the redox responses depicted in Figure 5. It confirms that the oxidation processes of molecule $\mathbf{1}$ form an irreversibly adsorbed product on the Pt electrode surface.

Conversely, molecule 7, which has a related molecular structure, shows quite different electrochemical properties. A representative CV of $\mathbf{7}$ is shown in Figure 6, where a welldefined and reversible couple is observed at $1.1 \mathrm{~V}$. The process has $\psi=1.80 \mathrm{~A}\left(\mathrm{~V} \mathrm{~s}^{-1}\right)^{-1 / 2} \mathrm{~cm}^{-2} \mathrm{M}^{-1}$, corresponding

(25) Nicholson, R. S.; Shain, I. Anal. Chem. 1964, 36, 706

(26) Nicholson, R. S.; Shain, I. Anal. Chem. 1965, 37, 178.

(27) Mastragostino, M.; Nadjo, L.; Saveant, J. M. Electrochim. Acta 1968, $13,721$.

(28) Miras, M. C.; Silber, J. J.; Sereno, L. Electrochim. Acta 1988, 33, 851.

(29) Fungo, F.; Otero L.; Durantini, E.; Thompson, W. J.; Silber, J. J.; Moore, T. A.; Moore, A. C.; Gust, D.; Sereno, L. Phys. Chem. Chem. Phys. 2003, 5, 464.

(30) Miras, M. C.; Silber, J. J.; Sereno, L. Electrochim. Acta 1988, 33 , 851.

(31) Seo, E. T.; Nelson, R. R.; Fritsch, J. M.; Marcoux, L. S.; Leedy, D. W.; Adamns, R. N. J. Am. Chem. Soc. 1966, 88, 3498.

(32) Marcoux, L. S.; Adamns, R. N.; Feldberg, S. W. J. Phys. Chem. 1969, 73,2623 .

(33) Nelson, R. F.; Feldberg, S. W. J. Phys. Chem. 1969, 73, 2623

(34) Creason, S. C.; Wheeler, J.; Nelson, R. F. J. Org. Chem. 1972, 37, 4440 .

(35) Nelson, R. F.; Philp, R. H. J. Phys. Chem. 1979, 83, 713.

(36) Bard, A. J.; Faulkner, L. R. Electrochemical Methods: Fundamentals and Applications; John Wiley \& Sons: New York, 1980.

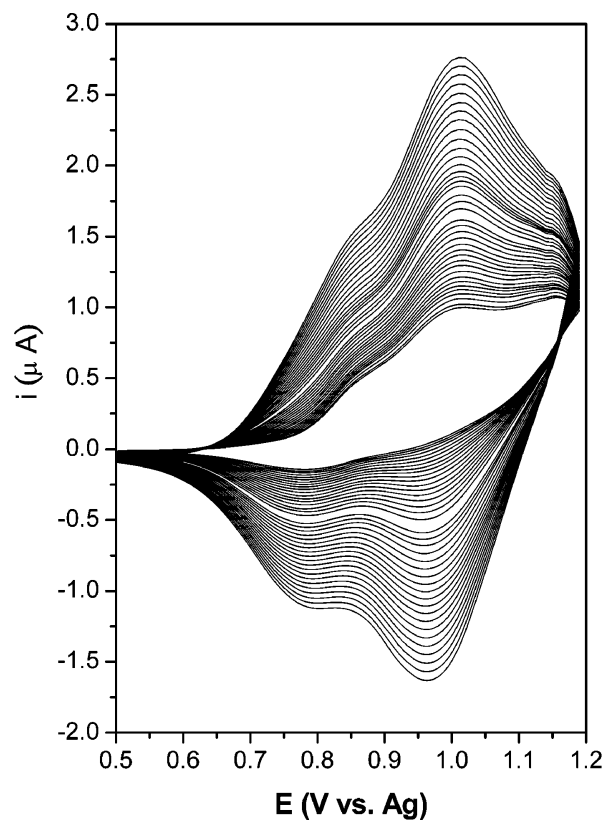

Figure 4. Repetitive cyclic voltammograms of the oxidation of a $1.0 \mathrm{mM}$ solution of 1 in MeCN with $0.1 \mathrm{M}$ TBAP on a Pt electrode, $v=0.1 \mathrm{~V} \mathrm{~s}^{-1}$, area of electrode $=2.16 \times 10^{-3} \mathrm{~cm}^{2}$.

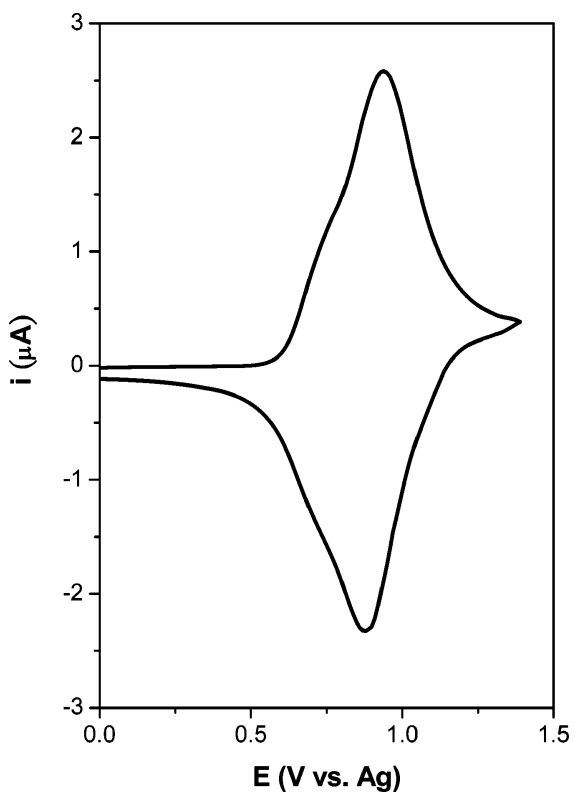

Figure 5. Cyclic voltammogram of the electro-deposited film derived from 1 on a Pt electrode in MeCN with $0.1 \mathrm{M}$ TBAP, $v=0.1 \mathrm{~V} \mathrm{~s}^{-1}$, area of electrode $=2.16 \times 10^{-3} \mathrm{~cm}^{2}$.

to the oxidation of the two amino moieties present in 7 at the same potential. The $i_{\mathrm{pc}} i_{\mathrm{pa}}$ relationship is approximately equal to 1 , indicating that the intermediates produced by the oxidation processes are stable in the time scale of a CV scan. Repetitive scans between 0 and $1.2 \mathrm{~V}$ show the same patterns observed in the first one, being affected only by the diffusion contribution, and the formation of new peak systems was not detected. This reversibility suggests that the radical cations of molecule $\mathbf{7}$ are more stable than the ones produced from electro-oxidation of $\mathbf{1}$. We proposed that when the TPA is also a constituent of the fluorene moiety, the dimer formation (TPB) is not efficient, because of the better radical cation stabilization through the rigid coplanar fluorene rings. We observed similar stabilization behavior in related 


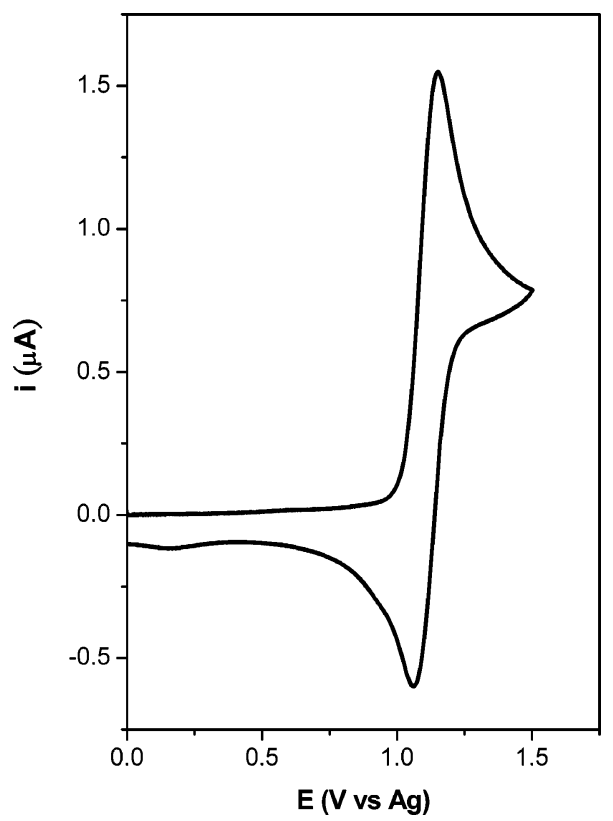

Figure 6. Cyclic voltammogram of molecule 7 on a Pt electrode in MeCN with $0.1 \mathrm{M}$ TBAP. $v=0.2 \mathrm{~V} \mathrm{~s}^{-1}[7]=8.56 \times 10^{-4} \mathrm{M}$, area of electrode $=2.16 \times 10^{-3} \mathrm{~cm}^{2}$.

TPA-spirobifluorene systems, for which we obtained fully reversible electro-oxidation processes. ${ }^{18}$ This stability avoids the formation of an electro-deposited film of molecule 7 when it is successively cycled.

On the other hand, it is interesting to note that in the molecules under consideration, we have two fluorene rings bonded perpendicularly through a common $\mathrm{sp}^{3}$ carbon atom, and the electron donor and acceptor are distributed in both fluorene rings (Scheme 1). This molecular geometry impedes $\pi$ orbital interactions between the two rings, and the inductive effects between the rings are minimal. In consequence, the redox potentials are only slightly affected by the substituents in a neighboring fluorene ring. It is expected that the electrontransfer number observed in the CV studies is the combination of the individual oxidation and reduction of the electrondonor and -acceptor components, respectively. ${ }^{18}$

Electrochemical Characterization of the Electrogenerated Film. The electrochemical response of molecule 1 films shows a stable behavior for more than several hundred cycles, and the same remains unchanged after air exposure and storage. Thus, this is congruent with the fact that there are not noticeable transformations in the film. Figure 5 shows that the film has a nearly symmetrical current response. At a low scan rate, the film presents anodic and cathodic peak potential separation $\left(\Delta E_{\mathrm{p}}=E_{\mathrm{pa}}-E_{\mathrm{pc}}\right)$ of around $0.1 \mathrm{~V}$, but at $v>0.1 \mathrm{~V} \mathrm{~s}^{-1}, \Delta E_{\mathrm{p}}$ shifts to larger values, which suggests nonideal behavior. ${ }^{36,37}$ However, similar $i-E$ profiles and identical peak systems are obtained regardless of the CV starting potential value. When the $\mathrm{CV}$ experiment is initiated at $1.4 \mathrm{~V}$ with a cathodic scan, the $\mathrm{CV}$ shape is very similar to the one showed in Figure 5. This fact suggests a high reversibility in the electrochemical behavior of the film and precludes instability as an explanation for the observed nonideal behavior. Furthermore, the oxidation charge of films

(37) Brown, A. P.; Anson, F. C. Anal. Chem. 1977, 49, 1589.

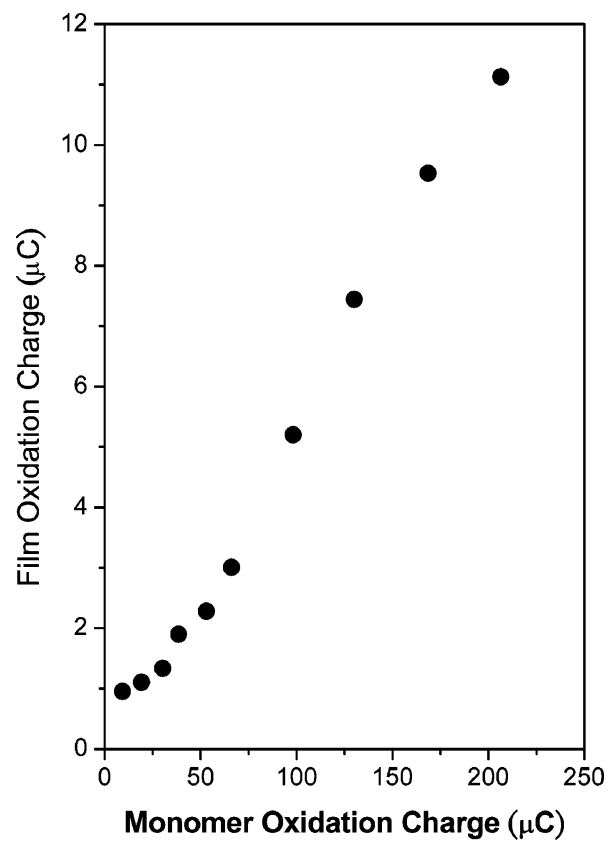

Figure 7. Film oxidation charge vs the anodic charge involved in the oxidation of monomer $\mathbf{1}$.

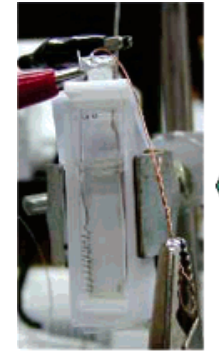

NEUTRAL

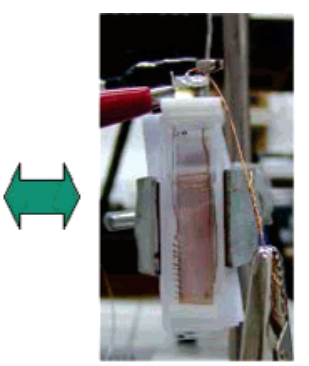

$0 x-1$

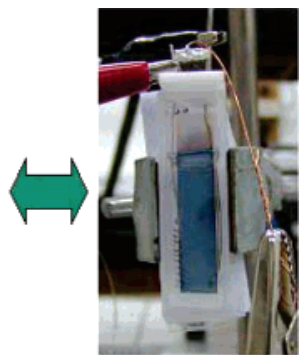

Ox-2
Figure 8. Pictures of molecule $\mathbf{1}$ film on the ITO electrode at different coloration states.

grows linearly with the monomer charge oxidations involved in the film formation, as shown in Figure 7. This observation is an indication of the good electrical conductivity of the film; we did not find a plateau or diminution in the film growing after more than 100 cycles in the film formation.

Spectroelectrochemical Characterization of the Electrogenerated Film. We performed a spectroelectrochemical study on the films of molecule $\mathbf{1}$ in order to obtain information about the possible molecular structure. To do that, the film was electro-deposited on an ITO electrode, where it showed the same characteristics of those obtained over a Pt electrode. During this experiment, we found a strong electrochromic effect and clear spectral changes. Those changes occur during the redox switching between oxidized and reduced forms of the film. The results observed imply that the electro-deposited films of molecule $\mathbf{1}$ have the potential for electrochromic applications. The ITO/1 film electrode was immersed in a $0.1 \mathrm{M}$ TBAP-MeCN solution and subjected to potential steps between the values where the film showed different electrochromic states. After each potential step, the current in the electrochemical system was allowed to decay to background before the optical absorption spectrum was taken. Figure 8 shows photographs of molecule 1 film in uncharged (neutral, pale yellow), half (Ox-1, red), and fully $(\mathrm{Ox}-2$, blue) oxidized states, taken under ambient 


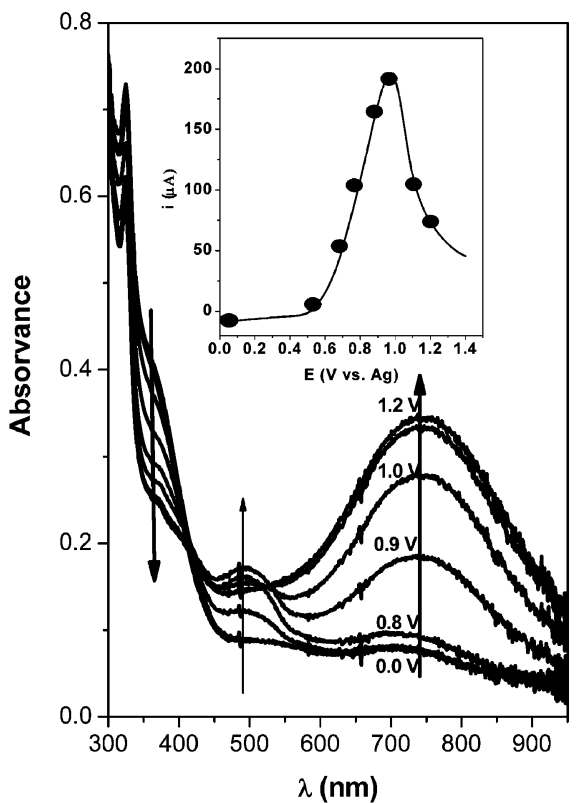

Figure 9. Absorption spectra of the electro-deposited film of molecule 1 on an ITO electrode at various applied potentials in $\mathrm{MeCN}$ with $0.1 \mathrm{M}$ TBAP. Inset shows the potentials at which spectra were obtained.

conditions. The pictures also show the experimental setup used in the spectroelectrochemical studies. The film colors are homogeneously distributed across the electrode surface, and the color changes are easily detected by the naked eye.

The absorption spectra of the electro-deposited film of molecule $\mathbf{1}$ were measured as a function of applied potentials between 0.0 and $1.3 \mathrm{~V}$ (Figure 9). In the neutral form at 0 $\mathrm{V}$, the film has a pale yellow color, with light absorption below $450 \mathrm{~nm}$. As the potential increased to positive values, the intensity of the shoulder at $364 \mathrm{~nm}$ (that extends to the visible region) decreased. On the other hand, the growth of two new absorption bands was observed. At first, the intensity of a peak at $495 \mathrm{~nm}$ started to increase and reached a maximum at potential values of around $0.9 \mathrm{~V}$, producing the observed red coloration of the film (Ox-1, Figure 8). The absorbance at $495 \mathrm{~nm}$ then started to decrease when the potentials became more anodic. Meanwhile, the intensity of the second absorption peak, with a wavelength maximum centered at $740 \mathrm{~nm}$, increased as the potential was gradually turned to around $0.8 \mathrm{~V}$ and reached a maximum at $1.2 \mathrm{~V}$. This absorption is ascribed to the fully oxidized state of the electro-deposited film of molecule 1 (Figure 8). Thus, the blue color (Ox-2, Figure 8) results from a decrease in light absorption at shorter wavelengths, associated with an increase of the broad absorption band at lower energy.

The spectroelectrochemical behavior of the electrodeposited film of molecule $\mathbf{1}$ agrees with the presence of tetraphenylbenzidine (TPB) in its molecular structure. As mentioned above, TPB is the product of the radical cation dimerization reaction of triphenylamine (TPA)..$^{13-15}$ The spectroelectrochemical data suggest that the TPB moiety is the electroactive center in the film. When the TPB molecule is oxidized in solution at potentials around $0.65 \mathrm{~V}$, it produces the radical cation, which has an absorption maximum at 480 $\mathrm{nm}$. At more-anodic potential, the TPB dication is produced, which has an absorption band maximum at $678 \mathrm{~nm} .{ }^{13}$ The absorption wavelength maximum of the electro-deposited

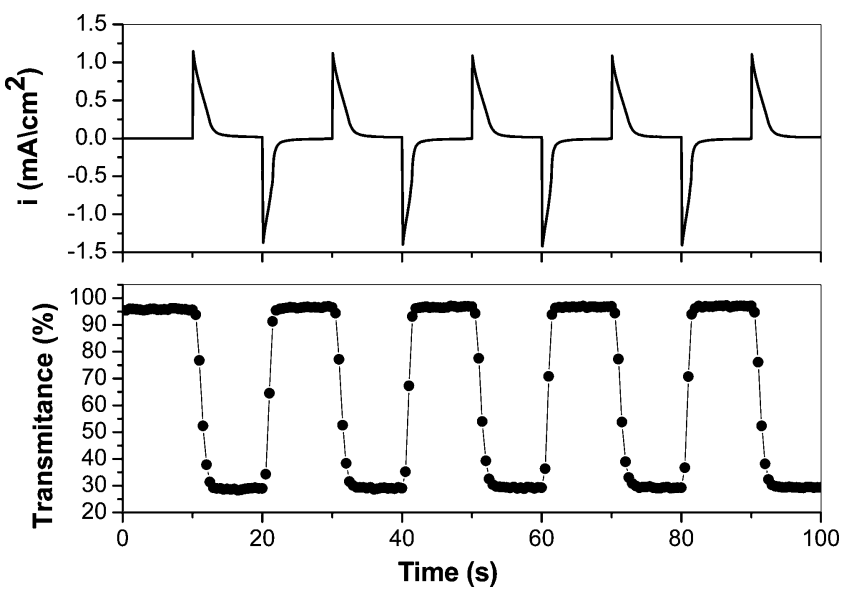

Figure 10. ITO/1 film electrochromic switching, current and optical response to a potential step between 0.5 and $1.3 \mathrm{~V}$ applied to the electrodeposited film of $\mathbf{1}$ in MeCN with 0.1 M TBAP. Absorption was recorded at $740 \mathrm{~nm}$.

film of molecule $\mathbf{1}$ is red-shifted with respect to those of TPB in MeCN solution. ${ }^{13}$ This difference could be attributed to the different dielectric environment in film.

To obtain an electrochromic parameter of molecule $\mathbf{1}$ film, we applied potential switching steps between the reduced and oxidized states, where the absorbance changes were monitored with the time. The ITO/1 film oxidation state was switched by stepping the potential between 0.5 and $1.3 \mathrm{~V}$, with time intervals of $10 \mathrm{~s}$, and the current and absorbance at $740 \mathrm{~nm}$ was monitored versus time. As is shown in Figure 10 , the current transient shapes of the oxidation and reduction current peaks are different, reaching zero in a few seconds during the potential pulses, but the charge injected in both processes are the same. Typically, in most electrochromic films, the oxidation of the neutral form (coloration step) proceeds more slowly than the reduction of the oxidized form (bleaching step) because of the difference in charge-transport rates between the two forms. ${ }^{38-41}$ In general, the absorbance switching follows the current switching, where the kinetics of the charge-transport process are reflected in the coloration response time. In the case of molecule 1 film, we estimate a response time required for $90 \%$ full-transmittance change at $740 \mathrm{~nm}$ of $1.7 \mathrm{~s}$ for the coloration step and $1.0 \mathrm{~s}$ for the bleaching step. On the other hand, the amount of charge $(Q)$ in each current curve in both processes was very similar, in agreement with the stable anodic electrochemical properties of molecule $1 \mathrm{film}$. This value of the charge was used to calculate the coloration efficiency, $\eta$, using the equation ${ }^{42} \eta$ $=\Delta A(\lambda) / Q$, where $Q$ is the injected charge per unit electrode area $\left(\mathrm{C} \mathrm{cm}^{-2}\right)$ and $\Delta A$ is the change in absorbance during a redox step of the device. The absorbance change at $740 \mathrm{~nm}$ under the same potential switching conditions as shown in Figure 10 yielded a blue coloration efficiency of ap-

(38) Panero, S.; Scrosati, B.; Baret, M.; Cecchini, B.; Masetti, E. Sol. Energy Mater. Sol. Cells 1995, 39, 239.

(39) Sapp, S. A.; Sotzing, G. A.; Reynolds, J. R. Chem. Mater. 1998, 10, 2101.

(40) De Paoli, M.-A.; Zanelli, A.; Mastragostino, M.; Rocco, A. M. J. Electroanal. Chem. 1997, 435, 217.

(41) Fungo, F.; Jenekhe, S. A.; Bard, A. J. Chem. Mater. 2003, 15, 1264.

(42) Monk, P. M. S.; Mortimer, R. J.; Rosseinsky, D. R. Electrochromism: Fundamentals and Applications; VCH: Weinheim, Germany, 1995. 
proximately $-308 \mathrm{C} \mathrm{cm}^{-2}$. This value is higher than that of electrochromic cells employing polyaniline ${ }^{43-45}$ and polypyrrole ${ }^{46}$ as the anodic coloring material and $\mathrm{WO}_{3}$ as the cathodic coloring material, ${ }^{42}$ but is lower than that of dual electrochromic cells composed with complementary electrochromic polymers, with total device $\eta$ values ranging from 250 to $1413 \mathrm{C} \mathrm{cm}^{-2} \cdot 39,46,47$

We also evaluated the contrast ratio for both colored states from the maximum transmission change observed in Figure 10. The transmittance of molecule $\mathbf{1}$ film in the neutral state (very pale yellow) is $97 \%$ and $29.7 \%$ in the fully oxidized state (blue) at $740 \mathrm{~nm}$. This gives a difference in the transmittance $(\Delta \% T)$ between those states of $67.3 \%$. The contrast achieved from the molecule $\mathbf{1}$ film is quite high when compared to other electrochromic polymer films. ${ }^{38-40,48-50}$ All these results concluded that the electropolymerized 1 films showed very good electrochromic characteristics under aerobic conditions, with a homogeneous change of color between three coloration states in a repetitive and reproducible behavior.

Formation Mechanism of the Electro-Deposited Film of Molecule 1. The observed spectroelectrochemical behavior strongly indicates the presence of a TPB moiety in the film structure and supports that the TPA radical cation dimerization reaction is involved in molecule $\mathbf{1}$ film formation. We propose that the oxidation of molecule $\mathbf{1}$ gives two separate triphenylamine radical cations, which dimerize rapidly to form TPB moieties. The efficient polymer formation is due to the particular molecular structure of molecule $\mathbf{1}$, in which two fluorene rings holding TPA substituents are perpendicularly bonded. This configuration precludes $\pi$-orbital interactions between the two D-A chromophore branches, ${ }^{18}$ allowing independent dimerization of both TPA substituents to occur smoothly. A possible polymer structure is depicted in Scheme 2. This polymer structure explicates the continuous film growth and the good conductivity due to the presence of TPB, an excellent hole transporter.

\section{Conclusions}

The efficient synthetic pathways of a novel spirobifluorene-based donor-acceptor (D-A) system have been successfully established. The obtained bipolar molecule (1)

(43) Jelle, B. P.; Hagen, G.; Odegard, R. Electrochim. Acta 1992, 37, 1377

(44) Michalak, F.; Aldebert, P. Solid State Ionics 1996, 85, 265.

(45) Panero, S.; Scrosati, B.; Baret, M.; Cecchini, B.; Masetti, E. Sol. Energy Mater. Sol. Cells 1995, 39, 239

(46) Arbizzani, C.; Mastragostino, M.; Zanelli, A. Sol. Energy Mater. Sol. Cells 1995, 39, 213.

(47) Rauh, R. D.; Wang, F.; Reynolds, J. R.; Meeker, D. L. Electrochim. Acta 2001, 46, 2023.

(48) Jelle, B. P.; Hagen, G.; Odegard, R. Electrochim. Acta 1992, 37, 1377.

(49) Marcel, C.; Tarascon, J. M. Solid State Ionics 2001, 143, 89.

(50) De Paoli, M. A.; Casalbore-Miceli, G.; Girotto, E. M.; Gazotti, W. A. Electrochim. Acta 1999, 44, 2983.
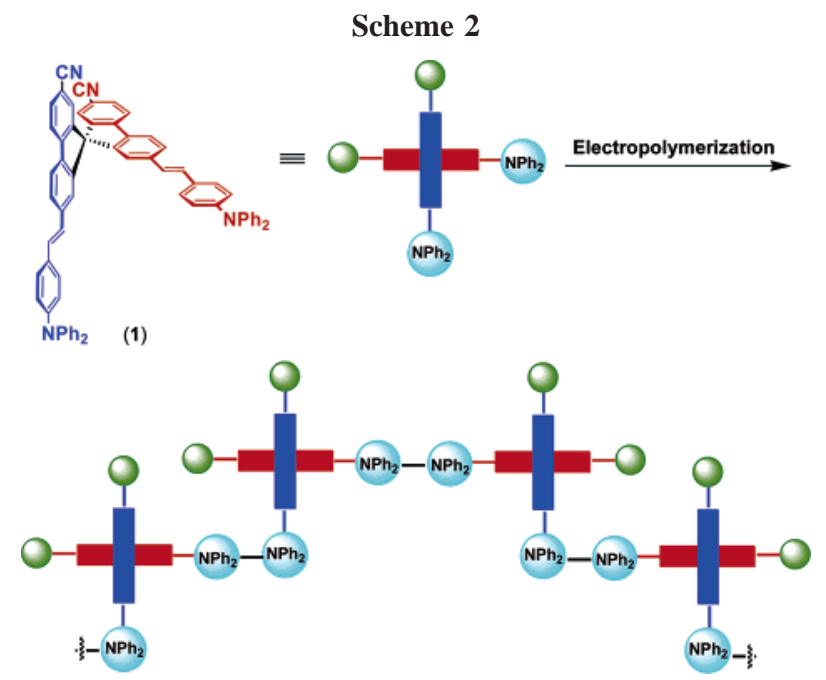

exhibits a fast photoinduced electron-transfer (PET) process probed by steady-state photophysical measurements. The unique molecular configuration impedes the extension of $\pi$-conjugation between two $\mathrm{D}-\mathrm{A}$ branches, which allows the donors (TPA) to act independently; this leads to the formation of a stable polymer film upon electro-oxidation. The polymer film showed reversible electrochemical processes and stable color change with high coloration efficiency and contrast ratio when the polymer was switched between the neutral and oxidized states under aerobic conditions. The excellent electrochromic behavior of the film can be clearly interpreted by spectroelectrochemical studies. The spectroelectrochemical studies also agree with the TPA dimerization mechanism mainly being involved in the eletropolymerization process. Thus, a plausible polymer structure was proposed. The kinetics of the charge-transport process in the film have been investigated by the coloration response time, showing that the polymer films are of high interest and promising potential as hole- and electron-transporting materials in organic devices. We are currently applying this polymer as an active material in organic photovoltaics and other optoelectronic devices; these results will be reported in due course.

Acknowledgment. This work is supported financially by the National Science Council (NSC) of Taiwan (NSC94-2113-M002-002). C.Y.L. thanks the NSC for supporting his summer research program (NSC93-2815-C-002-028M). We are grateful to Consejo Nacional de Investigaciones Científicas y Técnicas (CONICET-Argentina), Agencia Nacional de Promoción Científica y Tecnológica (ANPCYT-Argentina), Secretaría de Ciencia y Técnica de la Universidad Nacional de Río Cuarto (SECYT-UNRC), and Fundación Antorchas for financial support. L.O. and F.F are scientific members of CONICET.

CM0605264 